\title{
Sensitivity to fragmentation and spatial distribution of birds in forest fragments of northern paraná
}

\author{
Fernanda Cristina Marques ${ }^{1,2}$ \& Luiz dos Anjos ${ }^{1}$ \\ ${ }^{1}$ Programa de Pós Graduação em Ciências Biológicas, Departamento de Biologia Animal e Vegetal, \\ Universidade Estadual de Londrina, CP 6001, CEP 86051-990, Londrina, PR, Brazil. \\ ${ }^{2}$ Corresponding author: Fernanda Cristina Marques, e-mail: fernanda1081@gmail.com
}

\begin{abstract}
MARQUES, F.C., ANJOS, L. Sensitivity to fragmentation and spatial distribution of birds in forest fragments of northern paraná. Biota Neotropica. 14(3): e20130015. dx.doi.org/10.1590/1676-0603001513
\end{abstract}

\begin{abstract}
In this study we investigated the relationship between the sensitivity to forest fragmentation of bird species and their habitat spatial distribution. We hypothesized that a homogenous spatial distribution is associated to habitat-generalist species, which would tend to be less sensitive to forest fragmentation; in contrast, a heterogeneous spatial distribution would drive to an increase of sensitivity to forest fragmentation. We concentrated on analyses of the suboscine birds, which are known to be closely associated to microhabitats. Field data was obtained in the Parque Estadual Mata dos Godoy $\left(23^{\circ} 27^{\prime} \mathrm{S}, 51^{\circ} 15^{\prime} \mathrm{W}\right)$, southern Brazilian Atlantic forest. This reserve has high Biotic Integrity levels, with a relatively high number of recorded suboscines. Forty three species of suboscines were recorded, of which 21 species were considered to have high sensitivity and 22 to have low sensitivity to forest fragmentation. There was no association between levels of sensitivity to forest fragmentation and spatial distribution of suboscines. We only found significant correlation with the group of the subcanopy suboscines at the northern portion of Parque Estadual Mata dos Godoy. Therefore, we found a weak relationship between spatial distribution (habitat specialization) and sensitivity to forest fragmentation. The fact that habitat-specialist birds tend to live at the northern portion of Godoy State Park, which has the first type of terrain in a landscape to be converted into agriculture, indicate that that region has special importance for conservation.
\end{abstract}

Keywords: microhabitat, habitat-specialization, suboscine birds.

MARQUES, F.C., ANJOS, L. Sensibilidade à fragmentação e distribuição espacial de aves em fragmentos florestais do norte do Paraná. Biota Neotropica. 14(3): e20130015. dx.doi.org/10.1590/1676-0603001513

Resumo: Neste estudo nós investigamos as relações entre sensibilidade à fragmentação florestal de aves e sua distribuição espacial no habitat. Nossa hipótese é que a distribuição espacial homogênea está associada a espécies habitat-generalistas, que tenderiam a ser menos sensíveis à fragmentação florestal, em contrapartida, uma distribuição espacial heterogênea seria resultado de uma maior sensibilidade à fragmentação florestal. As análises foram concentradas em aves suboscines por serem intimamente associada a microhabitats. Dados amostrais foram obtidos no Parque Estadual Mata dos Godoy $\left(23^{\circ} 27^{\prime}\right.$ $\left.\mathrm{S}, 51^{\circ} 15^{\prime} \mathrm{W}\right)$, sul da Mata Atlântica brasileira. Esta reserva apresenta alto Índice de Integridade Biótica, com um número relativamente elevado de aves suboscines. Quarenta e três espécies de aves suboscines foram registradas, sendo 21 espécies consideradas de alta sensibilidade e 22 de baixa sensibilidade à fragmentação florestal. Não houve associação entre os níveis de sensibilidade à fragmentação florestal e a distribuição espacial de aves suboscines. Só foi observada significância para as aves de sub-bosque da porção norte do Parque Estadual Mata dos Godoy. Portanto, encontramos uma fraca relação entre especialização de habitat e sensibilidade à fragmentação florestal. O fato destas aves habitat-especialistas tenderem a viver na porção norte do Parque Estadual Mata dos Godoy, que é o primeiro tipo de terreno a ser convertido para a agricultura em uma paisagem, indicam que essa região tem uma importância especial para a conservação.

Palavras-chave: aves suboscines, habitat-especialistas, microhabitat.

\section{Introduction}

Forest fragmentation has been considered a major force in decreasing local biodiversity (e.g. Gardner et al. 2009, Laurance 2010). However, fragmentation does not act homogeneously on different species. In birds, several features have been identified as closely related to species that are more sensitive, such as population size, reproductive performance, annual survival, trophic position, rarity, and biogeographic position (e.g. Henle et al. 2004, Anjos 2006, Devictor et al. 2010). Another feature 
pointed out by Henle et al. (2004) associating sensitivity of bird species to forest fragmentation is habitat specialization. Species that are more habitat-specialists tend to be locally extinct where forests are fragmented (Ribon et al. 2003, Henle et al. 2004).

Variations in vegetation features, such as vertical and horizontal segregation associated with variations in floristic composition, increase diversity of microhabitats, which in turn drives to a mosaic of resources for the species, even in a continuous forest (Karr 1990). This structural complexity entails, for example, greater diversity of foraging substrates, as occurs in certain groups of birds, like the Furnariidae and Tyrannidae families (e.g. Remsen 2003, Fitzpatrick et al. 2004). Thus, a species could be found in certain habitats within a forest whilst being rare, or even absent, in others. Fragmentation can negatively affect the availability of those habitats for most specialized species, decreasing the chances of their survival in forest fragments (Uezu \& Metzger 2011). Therefore, habitat-specialist species may have their survival compromised due to the loss or alteration of vegetation heterogeneity (Cerqueira et al. 2003). However, the chances to persist in forest fragments should be higher in habitatgeneralists.

In this study we evaluated the type of spatial distribution of forest suboscine birds in a reserve of southern Brazil, the Parque Estadual Mata dos Godoy (PEMG). The principal microhabitat features of some suboscine species in PEMG have already been described (Poletto et al. 2004, Lopes et al. 2006, Volpato et al. 2006). Here we associated a homogeneous spatial distribution to habitat-generalist species, meaning that they could survive in larger spectrum of biotic and abiotic conditions within the forest. By contrast, species with heterogeneous spatial distribution were considered habitat-specialist, which indicates that they could not support a larger spectrum of environmental variations. We hypothesized that habitat-generalist suboscines are less sensitive to forest fragmentation than the habitat-specialists. The study was carried out in northern Paraná, where the sensitivity of species to forest fragmentation has been previously determined for several species (Anjos 2006). We considered firstly all species of suboscines together and secondly according their general feeding habits (canopy, subcanopy or climber). Additionally, we evaluated variations in the composition of the bird assemblies in the PEMG.

\section{Material and methods}

\section{Study area}

The study was conducted in Parque Estadual Mata dos Godoy (PEMG) $\left(23^{\circ} 27^{\prime} \mathrm{S}, 51^{\circ} 15^{\prime} \mathrm{W}, 656 \mathrm{ha}\right)$ located $15 \mathrm{~km}$ south of Londrina, Paraná, in southern Brazil. It is characterized as an important conservation area of northern Paraná. According to Anjos et al. (2009), it has a high value of Biotic Integrity $(0,85)$, with a high bird species richness (114 species) compared to other southern Brazil fragments, especially in light of the vegetation heterogeneity resulting from topographical variation between the north and south of the park (the top of the slope to the valley bottom, see Santana \& Anjos 2010). In this study, Anjos et al. (2009) determined an Index of Biotic Integrity (IBI) in 39 forest fragments in the north of Paraná State, southern Brazil, based on presence and absence of 30 selected bird species of different sensitivity levels to forest fragmentation.
The northern region of the PEMG, a plateau at about 600 $\mathrm{m}$ altitude, has a dense, closed canopy between $12 \mathrm{~m}$ to $20 \mathrm{~m}$ where the most abundant tree species are Cabraela canjerana (Meliaceae), Euterpes edulis (Arecaceae), Ocotea indecora (Lauraceae) and Nectandra megapotamica (Lauraceae) (Torezan \& Silveira 2002, Anjos et al. 2007). Because of the dense canopy, the midstory and understory receives little light, and the understory is relatively open, with short trees and bushes such as Eugenia verrucosa (Myrtaceae), Sorocea bonplandii (Moraceae), Miconiatritis (Melastomataceae), Maranta sp. (Marantaceae) and Piper sp. (Piperaceae) (Torezan \& Silveira 2002, Anjos et al. 2007). The southern portion consists of a sloped area $(600-470 \mathrm{~m})$ ending in a floodplain of the Apertados river, the southern boundary of the Park. The canopy is less compact, with the largest trees sparsely distributed, including Chrysophyllum gonocarpum (Sapotaceae), Campomanesia xanthocarpa (Myrtaceae) and Parapiptadenia rigida (Fabaceae). The midstory, however, has a higher density of smaller tree species, such as Nectandra megapotamica (Lauraceae), Alseis floribunda (Rubiaceae), Matayba elaeagnoides (Sapindaceae), Lonchocarpus muehlbergianus (Fabaceae), Sebastiana commersoniana (Euphorbiaceae), Eugenia verrucosa (Myrtaceae) and Trichilia cassaretti (Meliaceae) (Anjos et al. 2007, Santana \& Anjos 2010). It is common the fall of the tallest trees in this region, resulting in clearings dominated by the herbaceous Celtis iguanaea (Ulmaceae) and bamboo Chusquea sp. (Poaceae) (Silveira 2006, Anjos et al. 2007, Santana \& Anjos 2010). The edge of the park is characterized by a riparian forest floodplain which has little representation of the coverage in the PEMG; Bastardiopsis densiflora (Malvaceae) and Ocotea puberula (Lauraceae) are examples of trees that make up the vegetation in this portion of the Park (Silveira 2006).

\section{Field work}

Point counts of limited distance were sampled (always by the same observer) along three trails. Each trail has $1300 \mathrm{~m}$ length. Two trails were in the upland forest (TA and TB) and the third on the sloped forest in the southern area (TC). On each trail, 14 points were established every $100 \mathrm{~m}$ and numbered in sequence (one to 14, Figure 1). Field sampling was obtained at each point and conducted from October to

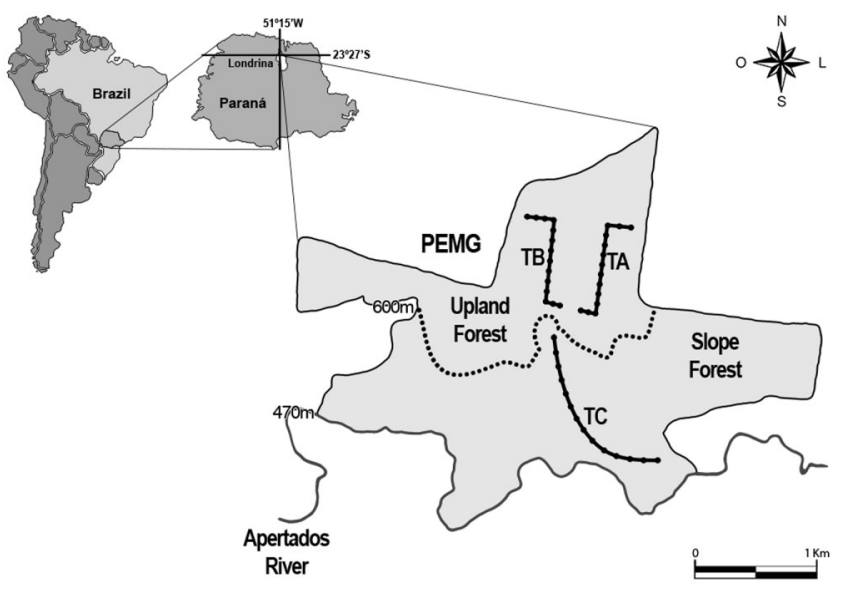

Figure 1. Location of sampling points in each of the three trails sampled in Parque Esta dual Mata dos Godoy, Londrina, Brazil. The dotted line indicates the division by altitude of the two types of forest in the Park. 
December 2011, beginning at sunrise. The radius of detection from each point was $50 \mathrm{~m}$. On each day, the trails were walked twice in opposite directions. The point samplings in a day were considered as one sample. The starting point of each trail sample was alternated each day, offering the same odds of detection for all species. The sampling period at each point was 5 minutes, thus it lasted for about four hours. At each point, only the presence of the species was registered.

\section{Vegetation characterization}

In order to evaluate whether the features of vegetation differ between the trails, general data on phyto-physiognomy were obtained at each point (36 points in total), by sampling at $25 \mathrm{~m}$ from each point along the trail and at $10 \mathrm{~m}$ from each side of the trail. Our sampled area for each point resulted in $1000 \mathrm{~m}^{2}$ (Figure 2). The vegetation variables that we collected were: number of large trees (height greater than $15 \mathrm{~m}$ ), number of palmettos (only Euterpe edulis occurs in PEMG, height greater than $4 \mathrm{~m}$ ) and herbaceous, liana and bamboo densities. The densities were estimated according to the proportion of the sample area occupied using the following scale: absent (0); to $40 \%$ (1); between 40-60\% (2); between $60-80 \%$ (3) and up to $100 \%$ (4). The sum of the percentages of herbaceous, liana and bamboo did not resulted in $100 \%$ because they were estimated independently. Our procedure was to estimate the area occupied for each of these three vegetation types.

\section{Procedure for analysis}

Levels of sensitivity to forest fragmentation of each bird species were based on Anjos (2006), which determined the sensitivity of bird species to fragmentation based on point counts conducted in 14 forest fragments of different sizes and degrees of isolation in northern Paraná. Species were considered highly sensitive if they occurred only in the controls and in large and not-isolated forest remnants; species with low sensitivity were those occurring in all categories of the forest remnants, including those smaller and more isolated (Anjos 2006). We considered the bird list of species of Anjos et al. (1997) to select the suboscines that occur in PEMG. We allocated each species to groups based on foraging habits, according to Remsen 2003, Marantz et al. 2003, Zimmer \& Isler 2003, Krabbe \& Schulenberg 2003, Whitney 2003, Krabbe \& Schulenberg 2003, Snow 2004, Fitzpatrick et al. 2004. The groups were: (1) canopy species, (2) subcanopy species, including species that frequent the ground and (3) climber species. We considered these distinct groups of species because they seem to present different levels of sensitivity to forest fragmentation. Subcanopy species seem to be more sensitive than canopy ones, while climbers seem to have intermediate sensitivity levels (Aleixo \& Vielliard 1995, Anjos \& Soares 1999, Ribon et al. 2003, Uezu \& Metzger 2011).

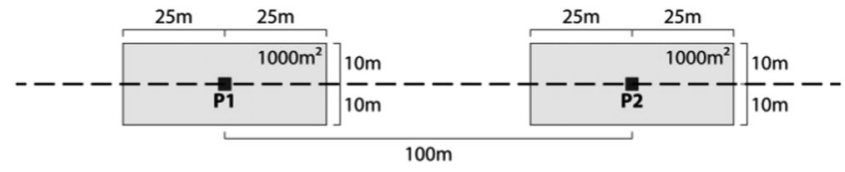

Figure 2. Schematic diagram of the sampling points (P1 and P2) and the sampled area in which the vegetation was characterized.

\section{Statistics and additional comments}

Kruskal Wallis analysis of variance was used to compare the variation in the number of trees and palmettos between trails studied (TA, TB and TC). For the remaining vegetation variables (density of vines, bamboo and herbaceous) it was used a contingency table $(p<0.05)$ to test whether the proportion of variables is similar in the three trails. This analyze was made by comparing the number of sampled areas wherein each vegetation variable was estimated according to the occupancy scale, in other words the number of sampled areas in each percentage range for each trail.

To evaluate whether bird species are habitat-generalist or habitat-specialist in PEMG we calculated the percentage of points that were occupied. To do this, we associated a homogeneous spatial distribution to habitat-generalist species, which would tend to be less sensitive to forest fragmentation. In contrast, we associated a heterogeneous spatial distribution to habitat-specialist species, which would tend to be more sensitive to forest fragmentation. Therefore, if a species was recorded at 4 points out of a total of 32 points from the trails, it would give us a percentage of $13 \%$ of occupancy. If another species was recorded at 28 points it would result in a percentage of $88 \%$ of occupancy. This way, we determined that species with an occupancy percentage equal and below 30\% were habitatspecialists and those above that value were habitat-generalist. In the first example the species would be habitat-specialist and in the second, habitat-generalist. The value of $30 \%$ was arbitrary selected. We know that detectability differs between the species, as has already been considered for some birds of the PEMG (Bochio et al. 2012). We countered this by sampling each point 12 times on 12 different days, making the possibility that a species was present but not recorded very low.

We evaluated the association between spatial distribution and the levels of sensitivity in the trails separately. As explained above, the distinction between homogenous and heterogeneous spatial distribution was based in the occupancy of the points; an occupancy equal and below 30\% were of heterogeneous spatial distribution (habitat-specialists) and those above that value were of homogenous spatial distribution (habitat-generalist). Contingency table $(p<0.05)$ was used to verify whether the spatial distribution (homogeneous and heterogeneous) was associated with sensitivity levels of suboscine species (sensitive and non-sensitive) or with foraging habits groups. All analyses were carried out using the software R.

Nonmetric multidimensional scaling (NMDS) was also used to examine the distribution of bird assemblies in the PEMG. For data analysis, the data were standardized and square-root transformed to reduce the effect of the most strongly represented species. For this data analysis, the relative frequency of each species at each point was used. Therefore, if a species was recorded 3 times out of 12 times a point was sampled, it had a frequency of occurrence of $40 \%$. This analysis was carried out using the software PRIMER 6.1.13 (Clarke \& Gorley 2006).

The sequence of species follows the checklist of the American Ornithologists' Union (2013).

\section{Results}

The number of large trees and palmettos and the densities of herbaceous plants were not significantly different among the studied trails (Tables 1, 2). However, higher density of bamboo 
Table 1. Mean $(X)$ and standard deviation (S) of vegetation variables in each trail. $P$ indicates the significance between the values of the variables between trails. (Kruskal Wallis).

\begin{tabular}{|c|c|c|c|c|c|c|c|}
\hline \multirow[t]{3}{*}{ Variables } & \multicolumn{6}{|c|}{ Trails } & \multirow[t]{3}{*}{$P$} \\
\hline & \multicolumn{2}{|c|}{ TA } & \multicolumn{2}{|c|}{ TB } & \multicolumn{2}{|c|}{ TC } & \\
\hline & $X$ & $S$ & $X$ & $S$ & $X$ & $S$ & \\
\hline Trees $(>15 \mathrm{~m})$ & 8,000 & 4.11 & 11,857 & 4.24 & 11,929 & 4.75 & 0.06 \\
\hline Palmettos $(>4 \mathrm{~m})$ & 7,500 & 6.49 & 9,714 & 9.33 & 7,286 & 6.57 & 0.79 \\
\hline
\end{tabular}

Table 2. Total sampled areas wherein each vegetation variable was estimated according to the following occupancy scale: absent (0); to $40 \%$; $(1)$ between $40-60 \%$ (2); between $60-80 \%$ (3) and up to $100 \%$ (4). $P$ value indicates the significance between trails. (G-test).

\begin{tabular}{|c|c|c|c|c|c|}
\hline \multirow{2}{*}{ Variables } & \multirow{2}{*}{ Scale } & \multicolumn{3}{|c|}{ Trails } & \multirow{2}{*}{$P$} \\
\hline & & TA & TB & TC & \\
\hline \multirow[t]{4}{*}{ Herbaceous stratum } & 1 & 1 & 0 & 2 & \multirow[t]{4}{*}{0.60} \\
\hline & 2 & 2 & 3 & 5 & \\
\hline & 3 & 9 & 9 & 6 & \\
\hline & 4 & 2 & 2 & 1 & \\
\hline \multirow[t]{4}{*}{ Vine } & 1 & 1 & 0 & 6 & \multirow[t]{4}{*}{0.01} \\
\hline & 2 & 4 & 5 & 5 & \\
\hline & 3 & 4 & 7 & 3 & \\
\hline & 4 & 5 & 2 & 0 & \\
\hline \multirow[t]{4}{*}{ Bamboo } & 1 & 14 & 14 & 4 & \multirow[t]{4}{*}{0.001} \\
\hline & 2 & 0 & 0 & 2 & \\
\hline & 3 & 0 & 0 & 3 & \\
\hline & 4 & 0 & 0 & 5 & \\
\hline
\end{tabular}

was found on TC $(\mathrm{G}=26.25, \mathrm{p}=0.001)$, while TA and TB had a higher density of vines $(\mathrm{G}=16.28, \mathrm{p}=0.01)$.

A total of 43 different suboscine birds were recorded; 36 species were seen in the northern and 40 in the southern portion of the PEMG. The numbers of species observed on each trail were: 34 species in TA, 32 species in TB and 40 in TC. For each trail there were (respectively on TA, TB and TC) 15, 13 and 13 species with a heterogeneous spatial distribution (habitatspecialists), and 19, 19 and 27 with a homogeneous spatial distribution (habitat-generalist). Overall, of the 43 species recorded in the present study, 21 were considered to have high sensitivity and 22 to have low sensitivity to forest fragmentation, following the literature cited above (see methods; Table 3). Among the high sensitivity species, 17, 16 and 19 species were found respectively on TA, TB and TC, whereas for species with low sensitivity, 18 were observed on TA, 16 on TB and 21 on TC.

There was no association between levels of sensitivity to forest fragmentation and spatial distribution of suboscine birds when the whole PEMG was considered $(\mathrm{G}=0.02, \mathrm{p}=0.87)$. Significance was only found in the group of subcanopy suboscine birds when TA and TB were considered separately $(\mathrm{G}=6.96, \mathrm{p}=0.008$ and $\mathrm{G}=4.41, \mathrm{p}=0.03$ respectively; Table 4). Subcanopy suboscine birds showed a significant association between homogeneous spatial distribution (habitatgeneralists) and low sensitivity to forest fragmentation. Canopy and climber suboscine birds did not exhibit significant association in any situation.
The nonmetric multidimensional scaling (NMDS) ordination revealed three distinct groups of bird species. One group is composed of species that preferentially occupy the northern portion, another of species that occupy the southern portion, while the third group consists of species that occupy the transition region between the northern and southern portions of the PEMG (Figure 3).

\section{Discussion}

We found an unexpectedly high number of suboscine birds with homogenous spatial distribution, which would suggest the majority of them could be considered habitat-generalists. This could mean that the studied suboscine birds are not closely associated to microhabitats as previously thought. In addition, contrary to our expectations, spatial distribution was not associated with level of sensitivity to forest fragmentation when all species of suboscine birds were considered together. This association was only found for the subcanopy suboscine birds and even then, only in the northern portion of the PEMG. These results should be considered carefully however, since it is possible that the area of forest sampled may not have been large enough to properly detect variations in habitat occupancy.

Subcanopy suboscine birds, or understory birds in general, have been seen as one of the more vulnerable groups to forest fragmentation (Willis 1979, Kattan 1994, Aleixo \& Vielliard 1995, Stouffer \& Bierregaard 1995, Bierregaard \& Stouffer 1997, Goerck 1997, Aleixo 1999, Stratford \& Stouffer 1999, 


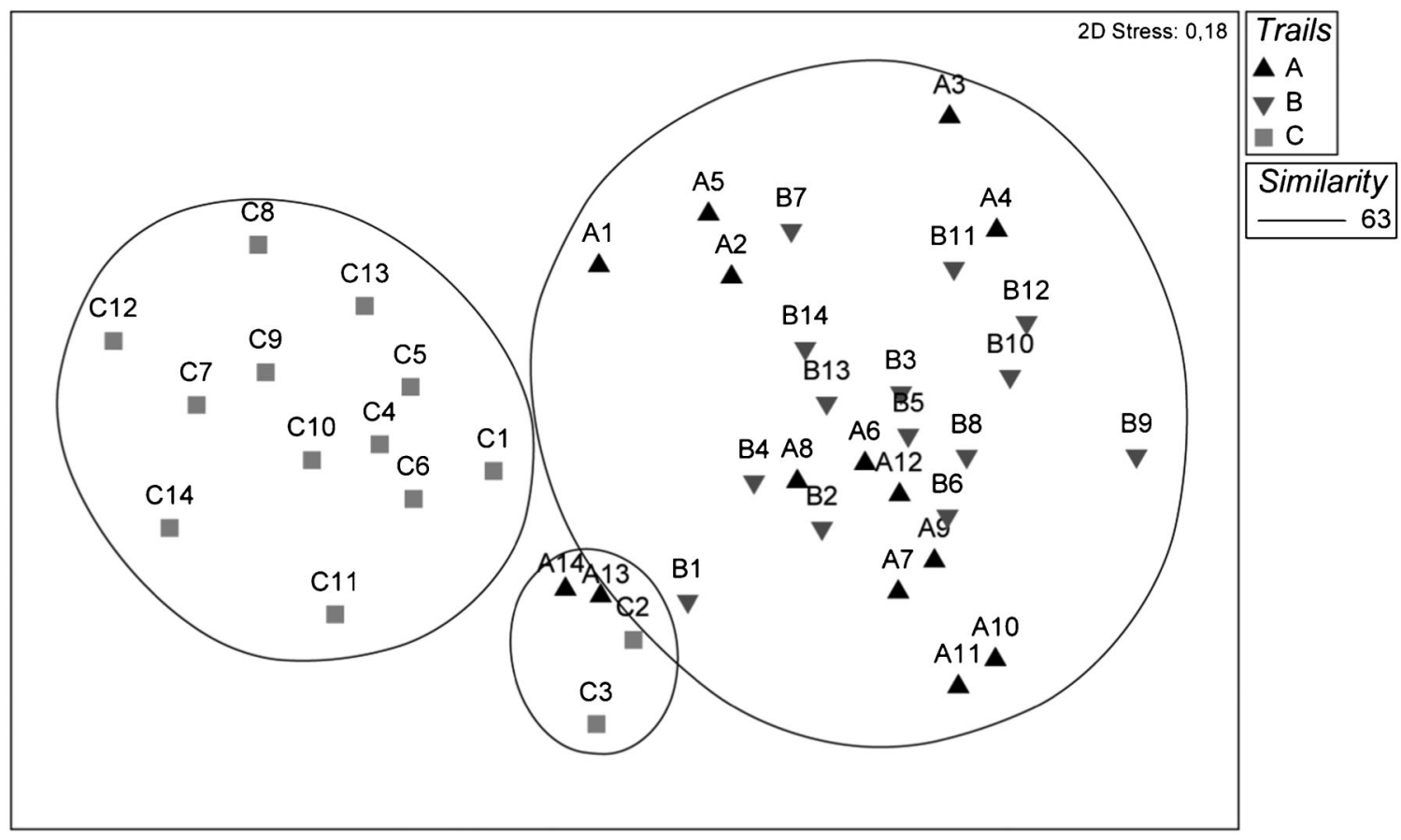

Figure 3. Nonmetric multidimensional scaling (NMDS) representing the profile similarity of sampling points according to the occupancy patterns of suboscine bird species sampled in Parque Estadual Mata dos Godoy.

Ribon et al. 2003, Henle et al. 2004, Lees \& Peres 2008, Uezu \& Metzger, 2011). Their habitat specialization is thought to be the reason for such higher vulnerability (Stratford \& Stouffer 1999, Hansbauer et al. 2008a, 2010, Sodhi et al. 2011), which seems to be corroborated by the data presented here.

Some studies claim that species of suboscine birds found on trunks and twigs, which we referred to as climbers in the present study, can be considered sensitive to even slight changes in the structure of vegetation (Willis 1979, Aleixo \& Vielliard 1995, Christiansen \& Pitter 1997, Anjos 1998, Poletto et al. 2004). Authors tentatively described the microhabitat of those birds, especially species of Dendrocolaptidae (Cintra et al. 2006, Poletto et al. 2004). However, the results of this study suggest that the reason for climbers being sensitive to forest fragmentation is not closely associated with the microhabitat specialization. Possibly their sensitivity could be the result of variations in vegetation structure at broader scales. According to Poletto et al. (2004), Dendrocolaptidae with stricter ecological requirements may relate with other vegetation features, selecting fairly homogeneous sites at late successional stages, such as Dendrocincla turdina, or even areas with tangled vegetation and rough bark large trees as Xiphocolaptes albicollis.

Canopy suboscine birds, in turn, do not appear to be associated with microhabitats. The canopy birds are adapted to move long distances seeking resources distributed unevenly in the canopy (Karr \& James 1975, Winkler \& Preleuthner 2001). Probably the broad potential of habitat occupancy (homogeneous spatial distribution) contributed to their low sensitivity to forest fragmentation (e.g. Karr 1982, Ribon et al. 2003, Uezu \& Metzger 2011).

The results found in the analysis of structural variation of the vegetation showed that PEMG can be differentiated according to the structure of understory vegetation, with it being subdivided into areas occupied predominantly by bamboos or vines. Large densities of bamboos were found only in the southern portion of the park (Silveira 2006, Santana $\&$ Anjos 2010). The bamboo clusters that make up the southern portion of the Atlantic Forest often occupy gaps and areas of secondary growth, especially in riparian forest or hills, where they have an aggregate distribution, forming a dense environment with a lower stratum of anatomically similar leaves (Kratter 1997, Santana \& Anjos 2010). Contrary to clusters of bamboo, vine tangles were found predominantly in the northern portion of the park. According to Kratter (1997), vine tangles are probably the most physiognomic similar microhabitat to clusters of bamboo, providing habitat and food source for many organisms (Schnitzer \& Bongers 2002, Thomsen et al. 2010). Data presented here (Table 3 and figure 3 ) revealed differences between the pattern of occupancy of the suboscine birds species between the areas occupied by bamboos and vines, which seems to disagree with the interpretations of Kratter (1997).

In the present study we found a weak relationship between spatial distribution (habitat specialization) and sensitivity to forest fragmentation. But our data suggested that suboscine birds occupied differently the northern and the southern portions of PEMG. Indeed, higher species numbers that have been considered as habitat-specialists were more common in the bird assembly of the northern portion of PEMG. The northern portion of the PEMG is the first type of terrain in a landscape to be converted into agriculture and should be considered as the most vulnerable area of that reserve. Many studies have evaluated effects of forest fragmentation comparing fragments of different sizes and levels of connectivity (e.g. Uezu et al. 2005, Hansbauer et al. 2008a, b, Gillies \& Clair 2010). But variations in the vegetation inside the forest fragment should be also considered in such studies (Hansbauer et al. 2010), as in the case of the PEMG. 


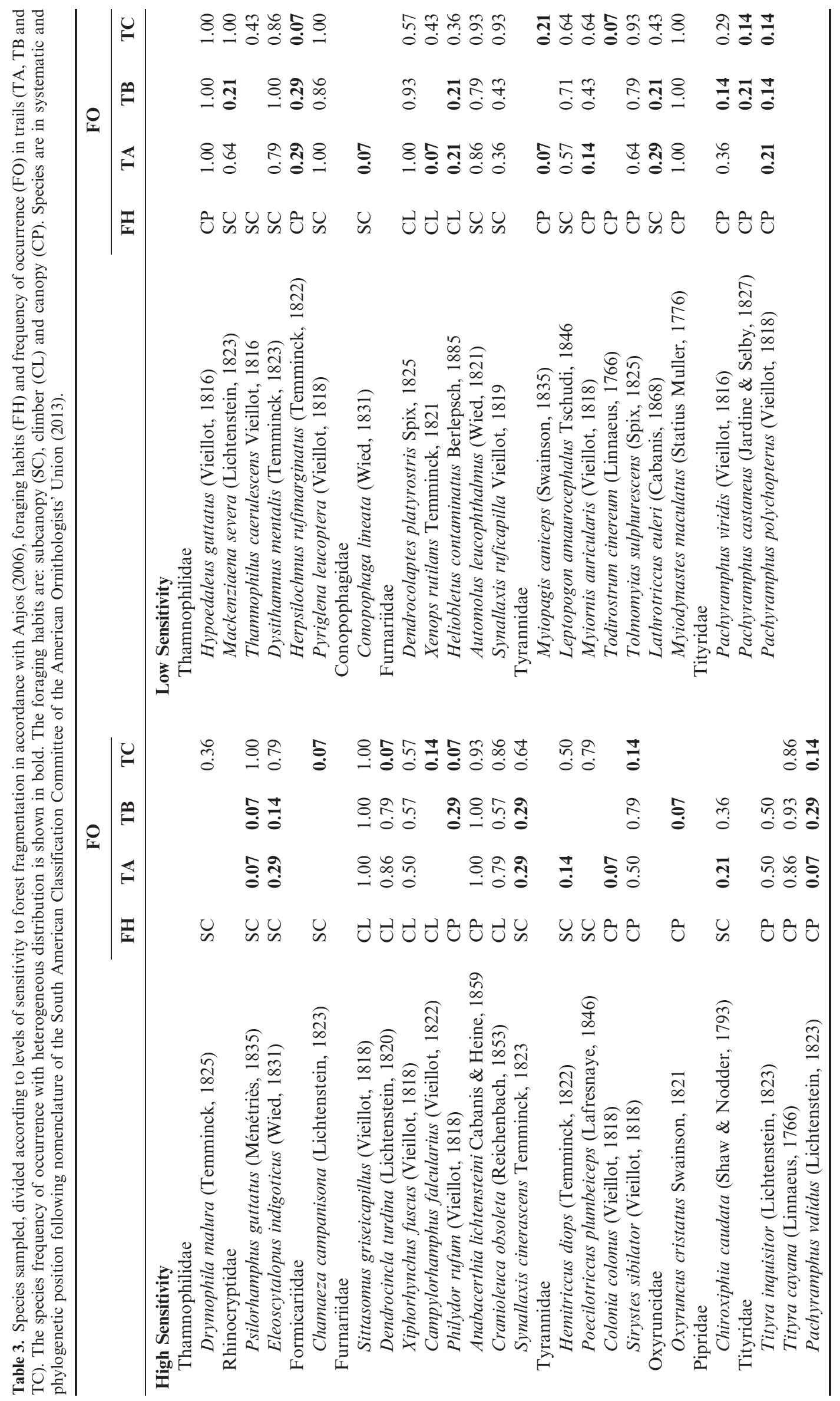




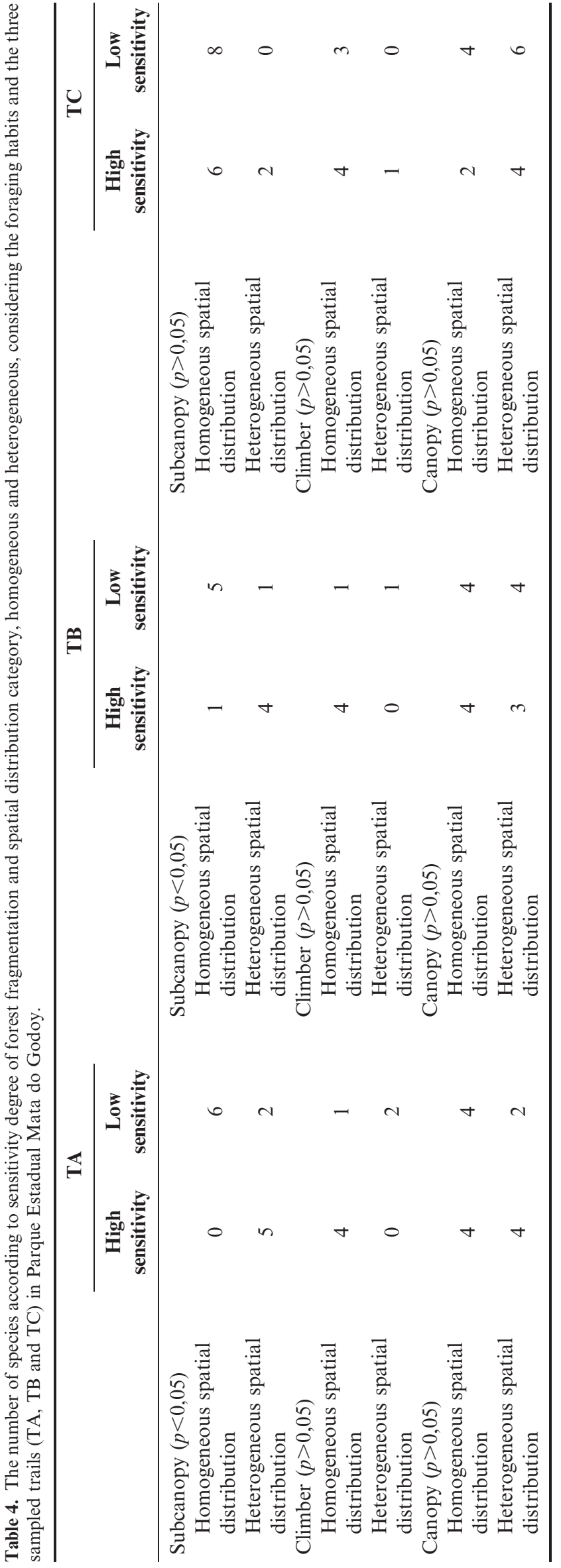

\section{Acknowledgments}

We thank Erivelto Goulart, Mario Luís Orsi, and Sandra Maria Hartz for revising a previous version of the manuscript, the Universidade Estadual de Londrina for logistical support and the InstitutoAmbiental do Paraná (252/10) for permission to conduct research in the Godoy State Park.

\section{References}

ALEIXO, A. 1999. Effects of selective logging on a bird community in the Brazilian Atlantic forest. Condor 101:537-548.

ALEIXO, A. \& VIELLIARD, J.M.E.1995. Composição e dinâmica da comunidade de aves da Mata de Santa Genebra, Campinas, SP. Rev. Bras. Zool. 12(3):493-511.

AMERICAN ORNITHOLOGISTS' UNION. 2013. Check-list of South American Birds. [Cited 20 May 2013.] Available from URL: http://www.museum.lsu.edu/ Remsen/SACCBaseline.html (last access on 20/05/2013).

ANJOS, L. 1998. Consequências biológicas da fragmentação no Norte do Paraná. Série. técnica. IPEF 12(32):87-94.

ANJOS, L. 2006. Bird species sensitivity in a fragmented landscape of the Atlantic Forest Southern Brazil. Biotropica 32(2):229-234. http://dx.doi.org/10.1111/j.1744-7429.2006.00122.x

ANJOS, L., SCHUCHMANN, K.L., BERNDT, R. 1997. Avifaunal composition, species richness, and status in the Tibagi river basin, Paraná State, southern Brazil. Ornitol. Neotrop. 8(2): 145-173.

ANJOS, L., SOARES, E.S. 1999. Efeito da fragmentacão florestal sobre aves escaladoras de tronco e galho na região de Londrina, norte do Estado do Paraná, Brasil. Ornitol. Neotrop. 10:61-68.

ANJOS, L., VOLPATO, G.H., LOPES, E.V., SERAFINI, P.P., POLETTO, F. \& ALEIXO, A. 2007. The importance of riparian forest for the maintenance of bird species richness in an Atlantic Forest remnant, southern Brazil. Rev. Bras. Zool. 24(4):1078-1086. http://dx.doi.org/10.1590/S0101-81752007000400027

ANJOS, L., BOCHIO, G.M., CAMPOS, J.V., MCCRATE, G.B. \& PALOMINO, F. 2009. Sobre o uso de níveis de sensibilidade de aves à fragmentação florestal na avaliação da Integridade Biótica: um estudo de caso no norte do Estado do Paraná, sul do Brasil. Rev. Bras. Ornitol. 17(1):28-36.

BIERREGAARD, R.O. \& STOUFFER, P C. 1997. Understory birds and dynamic habitat mosaics in Amazoniam rainforests. In Tropical forest remnants: ecology, management, and conservation of fragmented communities (Laurance,W.F. \& Bierregaard, R.O. eds). The University of Chicago Press, Chicago.

BOCHIO, G.M., ANJOS, L. 2012. The Importance of Considering Bird Detectability for Assessing Biological Integrity. Nat. Conservação 10:72-76. http://dx.doi.org/10.4322/natcon.2012.012

CERQUEIRA, R., BRANT, A., NASCIMENTO, M.T. \& PARDINI, R. 2003. Fragmentação: alguns conceitos. In Fragmentação de ecossistemas: causas efeitos sobre a biodiversidade e recomendações de políticas públicas (Rambalsi, D.M. \& Oliveira, D.A.S. eds). MMA/SBF, Brasília.

CHRISTIANSEN, M.M. \& PITTER, E. 1997. Species loss in a forest bird community near Lagoa Santa in Southeastern Brazil. Biol. Conserv 80(1):23-32. http://dx.doi.org/10.1016/S00063207(96)00073-0

CINTRA, R., MARUOKA, A.E. \& NAKA, L.N. 2006. Abundance of two Dendrocincla woodcreepers in relation to forest structure in Central Amazonia. Acta. Amazônica. 36(2):209-219. http:// dx.doi.org/10.1590/S0044-59672006000200011

CLARKE, K.R. \& GORLEY, R.N. 2006. Primer v6: user manual/ tutorial. PRIMER-E. Plymouth.

DEVICTOR, V., CLAVEL, J., JULLIARD, R., LAVERGNE, S., MOUILLOT, D., THUILLER, W., VENAIL, P., VILLEGER, S. \& MOUQUET, N. 2010. Defining and measuring ecological specialization. J. Appl. Ecol. 47(1):15-25. http://dx.doi.org/ 10.1111/j.1365-2664.2009.01744.x 
FITZPATRICK, J., BATES, J., BOSTWICK, K., CABALLERO, I., CLOCK, B., FARNSWORTH, A., HOSNER, P., JOSEPH, L., LANGHAM, G., LEBBIN, D., MOBLEY, J., ROBBINS, M., SCHOLES, E., TELLO, J., WALTHER, B. \& ZIMMER, K. 2004. Family Tyrannidae (Tyrant-flycatchers). In Handbook of birds of the world (del Hoyo, J., Elliot, A. \& Sargatal, J. eds). Cotingas to pipits and wagtails. Lynx Edicions, Barcelona, v.9, p. 170-463.

GARDNER, T.A., BARLOW, J., CHAZDON, R.L., EWERS, R.M., HARVEY, C.A., PERES, C.A. \& SODHI, N.S. 2009. Prospects for tropical forest biodiversity in a human-modified world. Ecol. Lett. 12(6):561-582. http://dx.doi.org/10.1111/j.1461-0248.2009.01294.x

GILLIES, C.S. \& ST CL.A.I.R., C.C. 2010. Functional responses in habitat selection by tropical birds moving through fragmented forest. J. App. Ecol. 47(1):182-190. http://dx.doi.org/10.1111/j.13652664.2009.01756.x

GOERCK, J.M. 1997. Patterns of Rarity in the Birds of the Atlantic Forest of Brazil. Conserv. Biol. 11(1):112-118. http://dx.doi.org/ 10.1046/j.1523-1739.1997.95314.x

HANSBAUER, M.M., STORCH, I., PIMENTEL, R.G. \& METZGER, J.P. 2008a. Comparative range use by three Atlantic Forest understorey bird species in relation to forest fragmentation. J. Trop. Ecol. 24(3):291-299. http://dx.doi.org/10.1017/ S0266467408005002

HANSBAUER, M.M., STORCH, I., LEU, S., NIETO-HOLGUIN, J.P., PIMENTEL, R.G., KNAUER, F. \& METZGER, J.P. 2008b. Movements of neotropical understory passerines affected by anthropogenic forest edges in the Brazilian Atlantic rainforest. Biol. Conserv. 141:782-791. http://dx.doi.org/10.1016/j.biocon.2008.01.002

HANSBAUER, M.M., VEGVÁRI, Z., STORCH, I., BORNTRAEGER, R., HETTICH, U., PIMENTEL, R.G. \& METZGER, J.P. 2010. Microhabitat Selection of three Forest Understory Birds in the Brazilian Atlantic Rainforest. Biotropica 42(3):355-362. http://dx.doi.org/10.1111/j.1744-7429.2009.00593.x

HENLE, K., DAVIES, K.F., KLEYER, M., MARGULES, C. \& SETTELE, J. 2004. Predictors of species sensitivity to fragmentation. Bio. Divers. Conserv. 13:207-251. http://dx.doi.org/10.1023/ B:BIOC.0000004319.91643.9e

KARR, JR. 1982. Avian Extinction on Barro Colorado Island, Panama: A Reassessment. Am. Nat. 119(2):220-239. http:// dx.doi.org/10.1086/283904

KARR,JR. 1990. Interactions between forest birds and their habitats: A comparative synthesis. In Biogeography and ecology of forest bird communities. ( Keast, A. ed). SPB Academic Publishing. Ann Arbor.

KARR, R. \& JAMES, F.C. 1975. Eco-morphological configurations and convergent evolution in species and communities. In Ecology and Evolution of Communities. (Cody, M.L. \& Diamond, J.M. eds). Harvard University Press. Cambridge.

KATtAN, G.H., ALVAREZ-LÓPEZ, H. \& GIRALDO, M. 1994. Forest fragmentation and Bird extinctions: San Antonio eighty years later. Conserv. Bio. 18(1):138-146. http://dx.doi.org/10.1046/ j.1523-1739.1994.08010138.x

KRABBE, N. \& SCHULENBERG, T. 2003. Family Formicariidae (Ground-antbirds). In Handbook of birds of the world (del Hoyo, J., Elliot, A. \& Sargatal, J. eds). Broadbills to tapaculos. Lynx Edicions. Barcelona, v.8, p. 682-731.

KRATTER, A.W. 1997. Bamboo specialization by Amazonian birds. Biotropica 29(1):100-110.

LAURANCE, W.F. 2010. Understanding habitat fragmentation in the real world. In The Theory of Island Biogeography Revisited. (Losos, J.B. \& Ricklefs, R.E. eds). Princeton University Press, New Jersey.

LEES, A.C. \& PERES, C.A. 2008. Avian life-history determinants of local extinction risk in a hyper-fragmented neotropical forest landscape. Anim. Conserv. 11(2):128-137. http://dx.doi.org/ 10.1111/j.1469-1795.2008.00162.x
LOPES, E.V., VOLPATO, G.H., MENDONÇA, L.B., FÁVARO, F.L. \& ANJOS, L. 2006. Abundância, microhabitat e repartição ecológica de papa-formigas (Passeriformes, Thamnophilidae) na bacia hidrográfica do rio Tibagi, Paraná, Brasil. Rev. Bras. Zool. 23(2):395-403. http://dx.doi.org/10.1590/S0101-81752006000200013

MARANTZ, C., AleiXo, A., BEVIER, L. \& PATTEN, M. 2003. Family Dendrocolaptidae (Woodcreepers). In Handbook of birds of the world (del Hoyo, J., Elliot, A. \& Sargatal, J. eds). Broadbills to tapaculos. Lynx Edicions, Barcelona, v.8, p. 358-447.

POleTtO, F., ANJOS, L., LOPES, E.V., VOlPATO, G.H., SERAFINI, P.P. \& FAVARO, F.L. 2004. Caracterização do microhabitat e vulnerabilidade de cinco espécies de arapaçus (Aves: Dendrocolaptidae) em um fragmento florestal do norte do estado do Paraná, sul do Brasil. Ararajuba. 12(2):89-96.

REMSEN, JR.J.V. 2003. Family Furnariidae (Ovenbirds). In Handbook of birds of the world (del Hoyo, J., Elliot, A. \& Sargatal, J. eds). Broadbills to tapaculos. Lynx Edicions, Barcelona, v.8, p. 162-357.

RIBON, R., SIMON, J.E. \& MATTOS, G.T. 2003. Bird extinctions in Atlantic forest fragments of Viçosa region, southeastern Brazil. Conserv. Biol. 17(6):1827-1839. http://dx.doi.org/10.1111/j.15231739.2003.00377.x

SANTANA, C.R. \& ANJOS, L. 2010. Associação de aves a agrupamentos de bambu na porção sul da Mata Atlântica, Londrina, Estado do Paraná, Brasil. Biota. Neotrop. 10(2): http:// www.biotaneotropica.org.br/v10n $2 /$ en/abstract?article+bn00510022010 ISSN 1676-0603 (last access on 21/05/2013).

SCHNITZER, S.A. \& BONGERS, F. 2002. The ecology of lianas and their role in forests. Trends. Ecol. Evol. 17(1):223-230. http:// dx.doi.org/10.1016/S0169-5347(02)02491-6

SILVEIRA, M. 2006. A vegetação do Parque Estadual Mata dos Godoy. In Ecologia do Parque Estadual Mata dos Godoy. (Torezan, J.M.D. Org). Itedes, Londrina, p. 19-27.

SNOW, D. 2004. Family Pipridae (Manakins). In Handbook of birds of the world (del Hoyo, J., Elliot, A. \& Sargatal, J. ). Cotingas to pipits and wagtails. Lynx Edicions, Barcelona, v.9, p. 110-169.

SODHI, N.S., SEKERCIOGLU, C.H., BARLOW, J. \& ROBINSON, S.K. 2011. Conservation of Tropical Birds. Wiley-Blackwell, Oxford.

STOUFFER, P.C. \& BIERREGAARD, R.O. 1995. Use of Amazonian forest fragments by understory insectivorous birds. Ecology 76(8):2429-2445.

STRATFORD, J.A. \& STOUFFER, P.C. 1999. Local extinctions of terrestrial insectivorous birds in a fragmented landscape near Manaus, Brazil. Conserv. Biol. 13(6):1416-1423. http://dx.doi.org/ 10.1046/j.1523-1739.1999.98494.x

THOMSEN, M.S., WERNBERG, T., ALTIERI, A., TUYA, F., GULBRANSEN, D., MCGLATHERY, K.J., HOLMER, M. \& SILliMAN, B.R. 2010. Habitat Cascades: The Conceptual Context and Global Relevance of Facilitation Cascades via Habitat Formation and Modification. Integr. Compe. Biol. 50(2):158-175. http://dx.doi.org/10.1093/icb/icq042

TOREZAN, J.M.D. \& SILVEIRA, M. 2002. Fatores ambientais, diversidade e similaridade em florestas da bacia do rio Tibagi. In A bacia do rio Tibagi. (Medri, M.E., Bianchini, E., Shibata, O.A. \& Pimenta, J.A. eds). Edição dos Autores, Londrina.

UEZU, A., METZGER, J.P. \& VIELLIARD, J.M.E. 2005. Effects of structural and functional connectivity and patch size on the abundance of seven Atlantic Forest bird species. Biol. Conserv. 123:507-519. http://dx.doi.org/10.1016/j.biocon.2005.01.001

UEZU, A. \& METZGER, J.P. 2011. Vanishing bird species in the Atlantic Forest: relative importance of landscape configuration, forest structure and species characteristics. Biodivers. Conserv. 20:3627-3643. http://dx.doi.org/10.1007/s10531-011-0154-5

VolPATO, G.H., ANJOS, L., POLETTO, F., SERAFINI, P.P., LOPES, E.V. \& FÁVARO, F.L. 2006. Terrestrial passerines in an Atlantic Forest remnant of Southern Brazil. Braz. J. Biol. 66(2A):473-478. http://dx.doi.org/10.1590/S151969842006000300013 
WHITNEY, B. 2003. Family Conopophagidae (Gnateaters). In Handbook of birds of the world (del Hoyo, J., Elliot, A. \& Sargatal, J. eds). Broadbills to tapaculos. Lynx Edicions. Barcelona, v.8, p. 732-745.

WILLIS, E.O. 1979. The composition of avian communities in remanescent woodlots in southern Brazil. Papéis Avulsos de Zoologia 33:1-25.
WINKLER, H. \& PRELEUTHNER, M. 2001. Behaviour and ecology of birds in tropical rain forest canopies. Plant. Ecol. 153:193-202. http://dx.doi.org/10.1023/A:1017595321548

ZIMMER, M. \& ISLER, M. 2003. Family Thamnophilidae (Typical Antbirds). In Handbook of birds of the world (del Hoyo, J., Elliot, A. \& Sargatal, J. eds). Broadbills to tapaculos. Lynx Edicions, Barcelona, v.8, p. 448-681. 